ISBN 978-93-84468-83-5

International Conference on Studies in Arts, Law, and Education

(ICALE-2016)

Singapore, Dec. 5-6, 2016

\title{
Reading Community for Students in Indonesia: Improving Knowledge and Experiences with Books
}

\author{
Pandu Purwadi \\ Padjadjaran University, Indonesia
}

\begin{abstract}
Nowadays most of Indonesian students do not have any interest in reading books. Also, they don't like to read books in daily lives and even not to touch it. Actually, books contain education, entertainment, and imagination contents. Thus, reading activity supports students cognition and imagination to explore environment around them and the situation in the world. They will open their mind and eyes by reading books. They reach and know unique cultures in every country. Reading can transfer education in life to reader by books like comics, novels, and other genres. School, library, and museum should give facilities for student's interest in reading books. This paper explains how to solve reading problem by establishing a reading community to improve students knowledges and experiences. A reading community accomodates students from any ages, such as childrens, teens and adults to enjoy books with group discussion, forum, and story telling.
\end{abstract}

Keywords: Culture, Education, Social.

\section{Introduction}

Education is one of the important sectors in developing countries, especially in Indonesia. It provides society with knowledge and skills and it has effects for society's welfare. Sumitro in Retno (2013) education is the way to increase human values and opportunities to organize their life [1]. These opportunities should doing for children and teenager in Indonesia, which one over four population composition in Indonesia are them. They are still young and there are many question and they can explore about life They are also in formal education process as students. In reality, Indoenesia face problem with education level. Suryawati in Hildegunda (2010) one of absolute poverty criteria is low education [2]. Based on statistic data from BPS (Badan Pusat Statistik) Indonesia 2015, there are 23,34\% students in Indonesia who have higher education, $75,51 \%$ students do not continue the formal education, and $1,14 \%$ population do not attend the formal education. education process is related to reading. In 2015, students' participation in some villages and cities in visiting library for reading is $11,75 \%$. This condition explains that students do not have any interest in reading books as soft or cognitive skill. In the other hand, hard skill related to students activities and contribution for organization or social responsibility is $91,93 \%$ students are not participatory, 2,21\% students participatory but not active, and 5,86\% students are participatory and active. Then, students whos take a part in organization and they have some purposes, 40,12\% students attend to improve knowledge, 13,04\% serving the society, 11, 57\% search for friends, $11,42 \%$ enjoy for free time, 8,95\% learn leadership, and the others like hobbies or business are 14,90\%. [3]. This is a real phenomenon of Indonesian students. They are not interested in reading books and most of them do not participate in social activities and organization, but several of them have interest in organization with educational purposes. The result students do not have soft skill, we know as knowledges and hard skill as experiences. Goverment and society should discuss the problem to improve quality of human resourse for future generation, because children and teenagers as student today, they will be successor for better Indonesia. 


\section{Literature Review}

\subsection{Reading Culture}

Risatyah and Mobit (2014) Reading is complex process to build understanding. it also can as tools of languages, communication, and share for idea [4]. It has positive effect for society for make interaction with other, for example they use foreign language for tourism and associate with the other culture and people around the world, they make good relation with communication between friends, colleagues, and workers. Every person has their mind so it will be easy to share ideas based on materials in books, but nowadays students in Indonesia focus on electronic media like television, smartphone, and computer. The statistic shows percentage of population in Indonesia from upper age 10 years old based on media interest. Three years are 2009, 2012, and 2015 data represent which media they had a week concern, watching television, listen to the radio, and reading magazine or newspaper. The table gives information, that most of population in Indonesia above $90 \%$ intense in watching television. Next, they listen to the radio had decreasing from 23,5\% in 2009, 18,55\% in 2012 and 7,54\% in 2015. Also in reading magazine or newspaper had decrease from $18,94 \%$ in $2009,17,66 \%$ in 2012 , and $13,11 \%$ in 2015. This table illustrates the percentage and reading is decreased in every years [5]. These are low reading culture in Indonesia, which have not interest to read books. They refer for watching TV and intens in electronic media, meanwhile we know the benefit from reading.

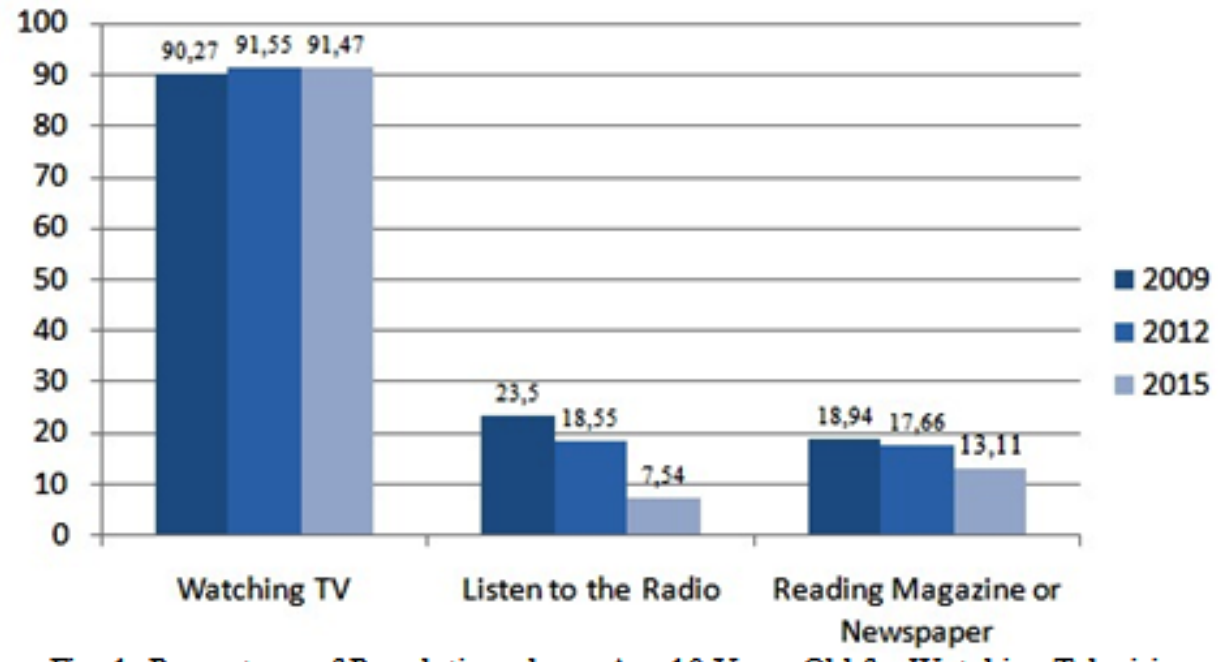

Fig. 1: Percentage of Population above Age 10 Years Old for Watching Television, Listen to the Radio, and Reading Magazine or Newaspaper in years 2009, 2012, and 2015

Munaf in Arisma (2012) students interaction with library is one of method to increase reading interest [6]. It gives effect for students, who do not have some books in their home. They can read and borrow books in library. Thus, the quiet condition is also suitable for students to read. This process will be success, if there are stimulus from library party to attract student visiting it. There are the ways to invite students, Leading educators Allington, Anderson, et all., McCracken \& McCracken, Routman, Trelease in Moser and Morrison (1998) explain four methods to invite students, who are as readers role to interest books by entering into a world, called the world of books. The methods are first teacher or librarian allow students to silent reading, second offering the type and genre of the books. Third, the materials can be shared with and by children, and the last providing approriate participation of adult in reading the book [7]. It better for part of school and library invite students to reading together. They need interaction with other students or friend, because interaction part of social process. Sarkiyah (2014) reading is not only related by cognitive abilities, it has mental, social, and emotional aspects, therefore it need fun and interactive ways [8]. The method for students to take and try reading should with help by teacher or librarian. Students read a book and then make calm atmosphere, like make rilex discussion session, its also can with story telling as fun and interactive ways. Darmono in Kasiyun (2015) the purposes of reading are for entertain, increase knowledge, and for doing a job [9]. Books give readers new knowledge and experiences, the 
other side students enjoy with fun actvities, because they have entertain. It like study and play process, in the next level, students have interest to reading books. Books have fiction and non-fiction, it contain different genres for fiction like romance, comedy, and horror. Non-fiction books are textbook or handbook for study and research. Its has benefit for their life gain knowledge from textbook and experiences in story of fantasy, it is also improve imagination and thinking.

\subsection{Community}

Spradly in Syafrudin and Hamidah (2009) community as group of society and they share importance experiences in the life [10]. Members in community can share their personal life and collect the other members experiences, and the result they know perspective from different character from them. Kertajaya Hermawan in Yamhap and Danela (2013) Community is a group of people, that they care with one another and it has strong personal relationship, because they have same interest and values [11]. Community is also as second family, because between members, there are strong bond to solve problem together, and each members know character, needs, and interest of all. Tonnies in Kusumastuti (2014) characteristic of community (gemeinschaft) are strong bond, private, and exclusive. Then the type of gemeinschaft are based on blood, place and mind. Gemeinschaft of mind related by same ideology and purpose on the society, meanwhile there are not blood and place relation [12]. Example for community of blood are family and brotherhood, community of place is teenagers union from one region, and community of mind is reading community. Based on Disablity service community building program : Practical guide explain the process of building a community like continue moving through mapping, planning, strategies, and reflection phases [13]. Community establish need process and time, first identify the area and interest in society, make and execute the plan and regulation to build structural in community, set strategies to take every challange and problem, and evaluate all process, fix the lack of system, then back to develope the community with mapping, planning, strategies, and reflection.

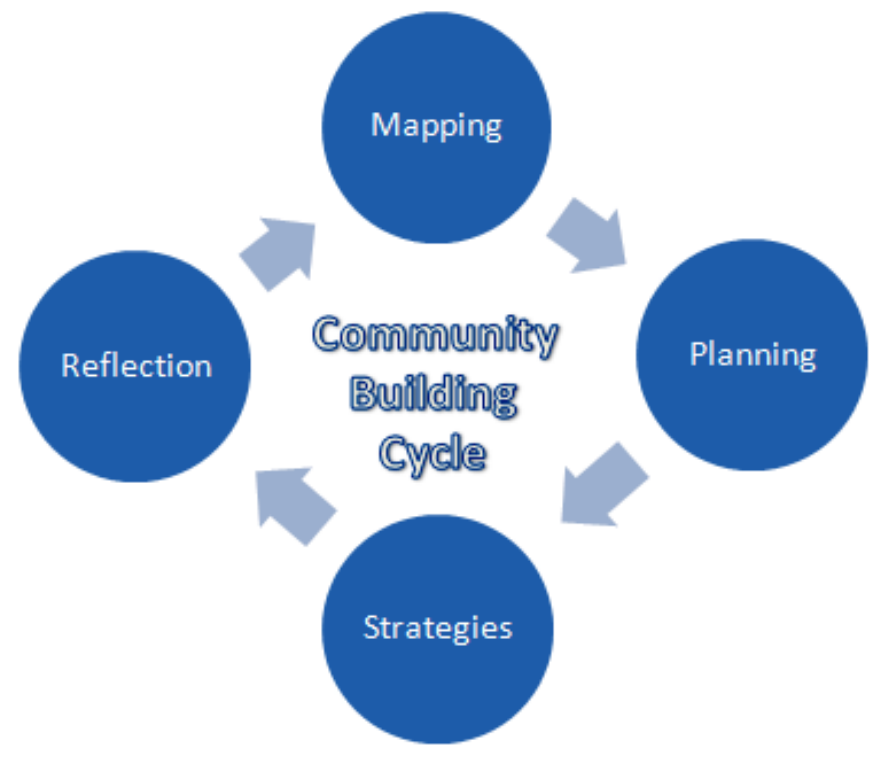

Fig. 2 Community Building Cycle

\section{Finding and Discussion}

\subsection{Combine Reading Culture and Community}

There are many type of community in the society. It appear to solve the problem, because it will be easy to handle together. In Bandung, there are community like Bandung Creative City Forum (BCCF). Fitriana in Hermawati and Runiawati (2015) creative community are one of important components in Bandung as creative city to develope in industries area. Community is a place to learn, share, and build the network [14].In this case, 
community can combine with every field such as health, education, and economics. So, society open for ideas and innovation to make a community related by education materials. Reading community is one of education sector for students. Alleman, and Knighton (2010) make classroom as a learning community. This is the concept that present classroom for students to take first action to learning and doing activities, which can solve the problem together with other students [15]. There are community for reading in Indonesia, like community of 1001 buku (1001books), they have volunteers activities for distribution and donating books for children, and there are virtual in internet like Komunitas Baca Buku (Community of reading books), place for readers and who want to be writer, there are many community of reading that can't explain in this paper, but they hasve same purpose to spread interest of reading book and help the society in education problem. Another reading community will more easy establish with help from school, library, museum or independent body in Indonesia.

\subsection{Role of Reading Community}

In the social aspect, Ife in Fauziyah (2015) There are community worker as member of community, who have four roles. First they are fasilitative role like support, organize, utilize the resourse and skills mediation, and negotiation. Second, educational role are increase public awareness, share information, and training. Third, delegation role are figure represent corporation with the other communities, like advocacy, make relationship and network. Last, technique role are figure to develope society with technical skills like analize data, presentation report, and management [16]. Students has important role in the society as developer and motivator for their friend, who not attend formal education. They give knowledge with social activities like make small library in village or lend books to the other. Also students as community worker can share experience and information and help their friend to improve soft skill and hard skill. It make valuable life for Indonesian students to take a part in positive activities. In education, students has spread knowledge for other and themself. They are not only get study materials, but also give it to society. They contribute and make real implementation in their environment. In culture, students grow positive habit to reading books. They share ideas and thinking together with friends, like discussion, read poetry, speech and story telling.

\section{Conclusion}

Reading community as solution idea for education, social, and culture problem in Indonesia. Students need establish reading community to improve their knowledge and experiences. It help them to increase interest in reading books with fun and interactive ways with friends, teachers, or librarians. Students also learn languages and communication abilities. Students have new family with strong relationship in community, take a part organization to develop the other and themself. Then, they are take as helpful role in community, because they have social activities for responsibility in society, and make contribution to improving interest reading books and spread positive ideas. The result, Indonesia has high quality human resource to be successor in the future.

\section{References}

[1] Retno, Ely Kusuma (2013), Pengaruh Pendidikan dan Kemiskinan terhadap Pertumbuhan Ekonomi di Indonesia. EJournal Unesa. [Online]. pp. 4. Available: http://ejournal.unesa.ac.id/article/5914/53/article.pdf

[2] Wini, H. “Analisis Faktor-faktor yang Mempengaruhi Jumlah Penduduk Miskin di Wilayah Pemekaran Tingkat Kabupaten (Studi Kasus Perbandingan Jumlah Penduduk Miskin Sebelum Dan Sesudah Pemekaran di Kabupaten Nagekeo Propinsi NTT Tahun 2005-2009),” Doctoral dissertation, UAJY., Yogyakarta, Indonesia, 2010.

[3] Susilo, Dwi; Ida Eridawaty Harahap, and Satriana Yasmuarto (Ed) (2015), Statistik Pemuda Indonesia 2015. BPS (Badan Pusat Statistik) Indonesia 2015 [Online]. pp. 36, 107, 119.

Available : https://www.bps.go.id/website/pdf_publikasi/Statistik-Pemuda-Indonesia-2015--.pdf

[4] Risatyah, Anisa and Mobit (2014). Penulusuran Minat Baca Karya Sastra Prosa : Studi Kasus Pada Mahasiswa Semester VI Prodi Pendidikan Bahasa Inggris Universitas Singaperbangsa, Karawang. Jurnal Ilmiah Solusi. [Online]. 1(3). pp. 41. Available: http://journal.unsika.ac.id/index.php/solusi/article/view/56/56 
[5] Susilo, Dwi; Ida Eridawaty Harahap, and Satriana Yasmuarto (Ed) (2015), Statistik Sosial Budaya 2015. BPS (Badan Pusat Statistik) Indonesia 2015 [Online]. pp. 26

Available : https://www.bps.go.id/website/pdf_publikasi/Statistik-Sosial-Budaya-2015--_rev.pdf

[6] Arisma, Olynda Ade (August 2012), Peningkatan Minat dan Kemampuan Membaca melalui Penerapan Program Jam Baca Sekolah di Kelas VII SMP Negeri 1 Puri. Jurnal Online UM. [Online]. pp. 19. Available : http://jurnalonline.um.ac.id/data/artikel/artikelE43071515F93A9AC37E1DEEDB096D065.pdf

[7] Moser, Gapy P. and Morrison T. G. (1998). Increasing Students' Achievement and Interest in Reading. Reading Horison. [Online]. 38(4) pp. 234.

Available : http://scholarworks.wmich.edu/cgi/viewcontent.cgi?article=1264\&context=reading_horizons

[8] Sarkiyah, S. (2014). Upaya Meningkatkan Keterampilan Membaca Permulaan Melalui Media Kartu di Kelas 1 Madrasa Ibtidaiyah Alkhairaat Uemalingku Kecamatan Ampana Kota. Jurnal Kreatif Tadulako Online, [Online] 4(4). pp. 138. Available : http://jurnal.untad.ac.id/jurnal/index.php/JKTO/article/viewFile/3305/2347

[9] Kasiyun, Suharmono. (2015). Upaya Meningkatkan Minat Baca sebagai Sarana untuk Mencerdaskan Bangsa. Jurnal Pena Indonesia (JPI). [Online] 1(1). pp. 81. Available : http://journal.unesa.ac.id/index.php/jpi/article/viewFile/140/61

[10] Kebidanan Komunitas, $1^{\text {st }}$ ed., EGC., Jakarta, 2009, pp. 1.

[11] Yamhap, Aleks and Danela, Rizky Okto (2013). Potret Komunitas Grunge (Studi pada kaum kucel di Bandar Lampung). Digilib Unila. [Online]. pp. 12. Available : http://digilib.unila.ac.id/id/eprint/272

[12] Kusumastuti, A. (2014). Peran Komunitas dalam Interaksi Sosial Remaja di Komunitas Angklung Yogyakarta (Doctoral dissertation, Universitas Negeri Yogyakarta.

[13] Disability Services Community Building Program : Practice Guide., State of Victoria., Melbourne, Australia, 2010, pp. $22-54$.

[14] Hermawati, Rina and Runiawati, Nunung. "Enhancement of Creative Industries in Bandung City Through Cultural, Community, and Public Policy Approaches". Presented at the ICLEH'15, Paris, France, November 25-26, 2015.

[15] Brophy, Jere; Alleman, Janet; and Knighton, Barbara, A Learning Community in the Primary Classroom, 1st ed. New York, U.S.A.: Taylor \& Francis, 2010, ch. 2, pp. 8.

[16] Fauziyah, Cika. "Peran Komunitas Save Street Child dalam Meningkatkan Kemandirian Anak Jalanan di Malioboro Yogyakarta”, Doctoral dissertation, Universitas Islam Negeri Sunan Kalijaga. Yogyakarta, 2015. 